\title{
The optical properties of astrophyllite from Narssârssuk, South Greenland
}

\author{
OLE V. PETERSEN
}

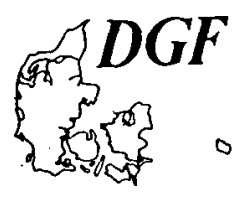

\begin{abstract}
Petersen, O. V., 1982: The optical properties of astrophyllite from Narssârssuk, South Greenland. Bull. geol. Soc. Denmark, vol. 30, pp. 67-69, Copenhagen, September 1st, 1982. https://doi.org/10.37570/bgsd-1981-30-06

The present investigation proves that astrophyllite from Narssârssuk, like astrophyllite from elsewhere, is biaxial positive and renders it probable that Bøggild's statement in his original description, that astrophyl-lite from Narssârssuk is biaxial negative, is due to a combination of misreading and miscalculation. Astrophyllite from Narssârssuk has $2 \mathrm{~V}_{\alpha}=98^{\circ} \pm 1^{\circ}-91^{\circ} \pm 1^{\circ} ; \alpha \perp$ to the mica-like cleavage (001) and $\gamma=$ the needleaxis (a), i.e. in optical orientation identical with astrophyllite from El Paso County, Colorado.
\end{abstract}

O. V. Petersen, Geologisk Museum, Københavns Universitet, Øster Voldgade 5-7, DK-1350 København K., Denmark, July 20th, 1981.

The optical properties of astrophyllite were first given by Des Cloizeaux (1862); according to Des Cloizeaux the axial angle of astrophyllite varies not only from crystal to crystal but also within single crystals. As an average he presents $2 \mathrm{H}=$ $118^{\circ}$ (red light). From this value Des Cloizeaux, with $\mathrm{n}_{\beta}=1.6$, calculated $2 \mathrm{~V}_{\{\alpha\}}$ * to be $103^{\circ} 25^{\prime}$, hence biaxial positive. All $\alpha$ and $\gamma$ in \{\} are added by the present author.

Brögger (1878) confirms the variation in $\mathrm{H}$ observed by Des Cloizeaux; according to Brögger astrophyllite is biaxial positive with $2 \mathrm{H}$ varying from $114^{\circ} 37^{1 / 2^{\prime}}$ to $123^{\circ} 28^{\prime}$ (white light).

Michel Lévy \& Lacroix (1888) were the first to determine the refractive indices of astrophyllite, $\mathrm{n}_{\alpha}=1.678, \mathrm{n}_{\beta}=1.703, \mathrm{n}_{\gamma}=1.733$; they also present astrophyllite as biaxial positive. The given $2 V_{\{y\}}\left(77^{\circ}\right)$ appears to be that of Des Cloizeaux (1862), but $2 \mathrm{~V}_{\alpha}$ calculated from the indices given $\left(93.82^{\circ}\right)$ is also in accordance with the mineral being biaxial positive.

Since these early descriptions, data on astrophyllite, from a rather large variety of localities, have been published (see e.g. Macdonald \& Saunders, 1973). With very few exceptions, astrophyllite is, whereever recorded, always recorded as biaxial positive.

One of these exceptions is presented by $\mathrm{O}$. B. Bøggild in his first description of astrophyllite from Narssârssuk, South Greenland. He writes, "The axial angle has in glass hemispheres been determined to: $2 \mathrm{H}=104^{\circ}$. If the index of refrac- tion of the hemisphere is 1.53 and the index $\beta$ of the astrophyllite is 1.733 , we get from this: $2 \mathrm{~V}=$ $88^{\circ} 10^{\prime}$. The axis of elasticity $\alpha$ being, as is otherwise the case, perpendicular to the direction of cleavage, it becomes here the acute bisectrix, and accordingly this astrophyllite, in contradiction to what is generally the case, is optically negative" (Bøggild 1907). Since no determination of $n_{\beta}$ or of the other principal indices of refraction are mentioned in the publication, we are fairly safe in concluding that Bøggild took his $n_{\beta}$ from the literature. Possibly the only refractive indices available were those of Michel Lévy \& Lacroix and it is striking that the $n_{\beta}$ used by Bøggild (1.733) is identical with $n_{\gamma}$ of Michel Lévy \& Lacroix. The present author is convinced that Bøggild in his calculation used the wrong $n_{\beta}$. Calculation based on the formula used by Bøggild $\sin \mathrm{V}=\mu \sin \mathrm{H} / \mathrm{n}_{\beta}$ where $\mu=1.53,2 \mathrm{H}=104^{\circ}$ and using the correct $n_{\beta}=1.703$ gives $2 V_{\alpha}=$ $90^{\circ} 14^{\prime}$, hence biaxial positive, or maybe more adequately optically neutral.

The investigation presented here was launched mainly to determine whether the astrophyllite from Narssârssuk is indeed optically negative or, like astrophyllite from elsewhere, optically positive. The astrophyllite from Narssârssuk is of a quite peculiar appearance; it is always formed as quite thin needles or rather as ruler-shaped bodies which for the greater part form hair-like or felt-like loose masses. Among the rather large material collected by the present author in 1969 


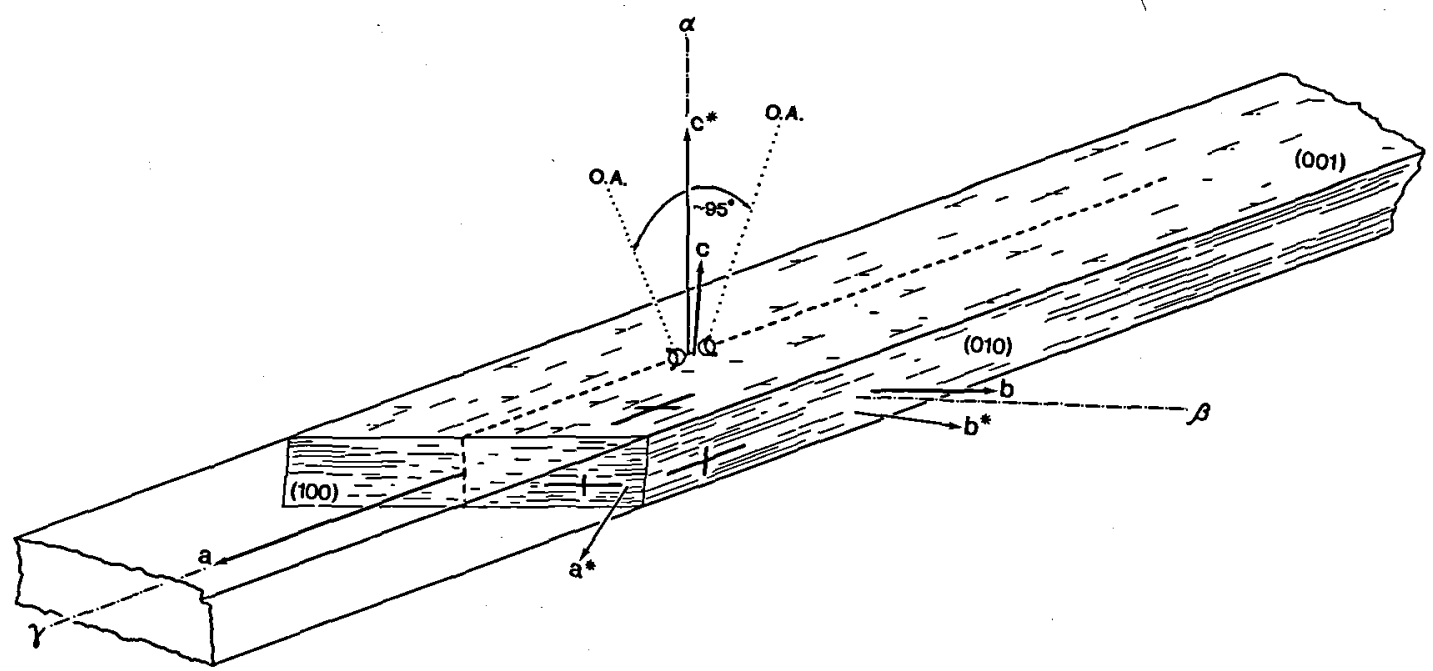

Fig. 1. Orientation of the indicatrix, $\alpha, \beta, y$ and optical axes (O.A.), the reciprocal axis $a^{*}, b^{*}, c^{*}$, and the axis $a, b$, and $c$ relative to the morphology in astrophyllite from Narssârssuk.

(Petersen et al. 1976), crystals as large as $20 \times$ $0.4 \times 0.1 \mathrm{~mm}$ have been found. Bøggild (1953) mentions very large $40 \times 18 \times 8 \mathrm{~mm}$ crystals of more common forms, i.e. mica-like. This material, bought from Greenlanders in 1907, 1908, and 1909 (altogether 5 catalogue numbers), however, does not originate from Narssârssuk sensu stricto but from a small nearby, mineralogically different pegmatite.

\section{Optics}

$2 V_{\alpha}$ and the orientation of $\alpha, \beta$, and $\gamma$ relative to the needle axis and the direction of mica-like cleavage, were determined on the universal stage in a series of thin sections cut obliquely to the needle axis. These measurements confirm the variation in $2 \mathrm{~V}_{\alpha}$ from crystal to crystal already observed by Des Cloizeaux (1862); $2 \mathrm{~V}_{\alpha}$ of astrophyllite from Narssârssuk varies from $98^{\circ} \pm 1^{\circ}$ to $91^{\circ} \pm 1^{\circ}$ but never becomes less than $90^{\circ}$, i.e. astrophyllite from Narssârssuk is, as astrophyllite from elsewhere, biaxial pos.; $v \ll r$. It has $\alpha \perp$ to the mica-like cleavage and $\gamma=$ the needle axis.

In order to relate the morphology, and thereby the optics, to the unit cell $a=5.36 \AA, b=11.76$ $\AA, c=21.08 \AA, \alpha=85^{\circ} 01^{\prime}, \beta=90^{\circ} 00^{\prime}$, and $\gamma=$ $103^{\circ} 13^{\prime}$ (Woodrow, 1967), an oscillation photo- graph with the needle axis as oscillation axis and a precession photograph of the reciprocal lattice plane $\perp$ to the needle axis were prepared. These photographs proved the needle axis to be the $5.36 \AA$ a-axis, and the reciprocal lattice plane to be the $b^{*}-c^{*}$ plane with $c^{*} \perp$ to the mica-like cleavage, the mica-like cleavage of the Narssârssuk astrophyllite thus being a cleavage after (001). Astrophyllite from Narssârssuk further shows good cleavage after (010) and fairly good but somewhat irregular cleavage after (100).

The results of this investigation are summarized in Fig. 1; note especially that this triclinic mineral shows parallel extinction on all faces in the zone [100] including the two pinacoids (001) and (010), as well as on the third pinacoid (100). On (100) and (010) the extinction is parallel to the trace of the mica-like cleavage, and on (010) and (001) parallel to the needle axis. The optical orientation in astrophyllite from Narssârssuk is identical to the optical orientation found in astrophyllite from El Paso County, Colorado, the only similar investigation that has previously been published (Nickel et al., 1964).

Acknowledgements. Thanks are due to J. Bailey who kindly corrected the English of the manuscript. 


\section{References}

Brögger, W.C. 1878: Untersuchungen norwegischer Mineralien. Z. Krist. u. Miner, II, 275-290.

Bøggild, O. B. 1907: On some mincrals from Narssârssuk at Julianehåb, Greenland. Meddr Grønland, 33, 95-120.

Bøggild, O. B. 1953: The mineralogy of Greenland. Meddr Gronland, 149 (3), $442 \mathrm{pp}$.

Cloizeaux, A. Des, 1862: Manuel de Minéralogie I, 1-527. Dunot, Paris.

Macdonald, R. and Saunders, M. J. 1973: Chemical variation in minerals of the astrophyllite group. Miner. Mag., 39, 97-111.
Michel Lévy, A. and Lacroix, A. 1888: Les Minérauxx des Roches, 1-334. Baundry et Cie, Paris.

Nickel, E. H., Rowland, J. F. and Charette, D. J. 1964: Niobophyllite - The niobium analogue of astrophyllite; A new mineral from Seal Lake, Labrador. Can. Miner., 8, $40-52$.

Petersen, O. V., Johnsen, O. and Leonardsen, E. S. 1976: Nordstrandite from Narssârssuk, Greenland. Miner. Rec., 2, 79-82.

Woodrow, P. J. 1967: The crystal structure of astrophyllite. Acta Cryst., 22, 673-678. 